\title{
The Investigation of Relationship Between Annexin A1 Gene Expression and Inflammation in Colorectal Cancer Patients
}

\section{Kolorektal Kanser Hastalarında Annexin A1 Gen Ekspresyonu ve İnflamasyon İlişkisinin İncelenmesi}

\author{
Filiz Bakar Ateş', Dılşa Mızrak Kaya² \\ ${ }^{1}$ Ankara Üniversitesi, Eczacılık Fakültesi, Biyokimya Anabilim Dalı, Ankara, Türkiye \\ ${ }^{2}$ Teksas Üniversitesi, M.D. Anderson Kanser Merkezi, Gastrointestinal Tıbbi Onkoloji Departmanı, Houston, \\ Teksas, ABD
}

\section{ÖZE'}

GİRIŞ ve AMAÇ: Annexin A1 (AnxA1) proteini, çok sayıda hücre ve dokuda eksprese olan ve inflamatuvar yanıtı bloke eden bir proteindir. Günümüzde oldukça yaygın görülen bir kanser türü olan kolorektal kansere inflamasyon gelişimi eşlik etmektedir. Bu çalışmada AnxA1 proteininin kolorektal kanserde inflamasyon gelişimi üzerine etkisinin değerlendirilmesi amaçlanmıştır.

YÖNTEM ve GEREÇLER: Çalışma 74 kolorektal kanser hastası ve 79 sağlıklı kontrol grubu ile gerçekleştirilmiştir. Gönüllülerden toplanan kan örneklerinden serum ve RNA izolasyonu yapılmıştır. Dolaşımdaki AnxA1 ve interlökin-6 (IL-6) düzeyleri ile sitozolik ve sekretuvar fosfolipaz A2 (cPLA2, sPLA2) aktiviteleri Elisa yöntemi ile saptanmıştır. AnxA1 ve PLA2 mRNA ekspresyon düzeyleri ise real-time PCR yöntemi ile ölçülmüştür.

BULGULAR: Hasta grubunda serum AnxA1 düzeyleri anlamlı olarak azalmış iken, IL-6 ve sPLA2 düzeylerinin arttığı saptanmıştır. AnxA1 mRNA ekspresyonu da kontrol grubuna göre anlamlı olarak azalmıştır. AnxA1 düzeyindeki azalmanın, inflamasyon belirteçlerindeki artış ile korelasyon gösterdiği saptanmıştır.

TARTIŞMA ve SONUÇ: Bu çalışma, kolorektal kanser hastalarında AnxA1 plazma protein düzeyleri ve mRNA ekspresyonu üzerindeki anlamlı değişiklikleri göstermiştir. Elde edilen sonuçlar, AnxA1 proteinin kolorektal kanserde görülen inflamasyon ile ilişkili olabileceğini göstermiştir. Annexin protein sistemindeki disregülasyon mekanizmasının aydınlatılabilmesi için ileri çalışmalara ihtiyaç duyulmaktadır.

Anahtar Kelimeler: Annexin A1, Fosfolipaz A2, İnflamasyon, Kolorektal Kanser

\begin{abstract}
INTRODUCTION: Annexin A1 (AnxA1) is a protein that inhibits the inflammatory response and is expressed by various types of cells and tissues. Colorectal cancer, a very common type of cancer today, is accompanied by the development of inflammation. At present study, it has been aimed to evaluate the relationship between AnxA1 protein and the development of inflammation in colorectal cancer.

METHODS: The study was conducted with 74 colorectal cancer patients and 79 healthy patients as the control group. Serum and RNA were isolated from the blood samples collected from volunteers. AnxA1 and interleukin6 (IL-6) levels in circulation as well as the activity of cytosolic and secretory phospholipase A2 (cPLA2, sPLA2) were determined using Elisa method. AnxA1 and PLA2 mRNA expression levels were measured by real-time PCR technique.

RESULTS: While serum AnxA1 levels were significantly decreased in patients group, IL-6 and sPLA2 levels were detected to be increased. AnxA1 mRNA expression was also significantly reduced compared to the control group. The decrease in AnxA1 level was found to correlate with the increase in inflammation markers. DISCUSSION and CONCLUSION: The present study has shown significant changes on AnxA1 plasma protein levels and mRNA expression in colorectal cancer patients. The data have revealed that AnxA1 protein may be associated with inflammation in colorectal cancer. Further studies are needed to elucidate the mechanism of dysregulation in the Annexin protein system.
\end{abstract}

Keywords: Annexin A1, Phospholipase A2, Inflammation, Colorectal Cancer 


\section{INTRODUCTION}

Colorectal cancer is one of the most common gastrointestinal cancers in the world today, and is the leading cause of cancer-related deaths (1-3). According to the 2004-2006 cancer statistics of Turkish Ministry of Health, the age-standardized incidence rate of colorectal cancer in Turkey has been recorded as 17.0 in men and 11.7 in women per 100.000 persons per year (4).

The functional relationship between inflammation and cancer is known for a long while. This relationship is based on the observation of tumors occuring in chronic inflammatory sites, the presence of inflammatory cells, chemokines and cytokines in tumors, the induction of cancer by overexpressed cytokines and chemokines, the activation or inhibition of the same molecular targets or similar pathways in the process of inflammation and carcinogenesis (5). There is a large body of literature that supports the link between colorectal cancer and chronic inflammation, and gastrointestinal inflammation has a supporting role in the development of colorectal cancer. While the incidence of colorectal cancer is increasing in inflammatory bone diseases, anti-inflammatory therapy is known to reduce the gastrointestinal neoplasm (6).

Several studies have been carried out to investigate the effects of various inflammatory markers on cancer development and metastasis. (7). In recent years, attention has been drawn to the role of cyclooxygenases in tumor development and progression (8). Eicosanoids, the products of the cyclooxygenase and lipoxygenase pathways, contribute to cancer progression by directing cell proliferation, motility, invasion and angiogenesis (9). Increased prostaglandin (PG) levels are observed in many human cancer types due to the upregulation of cyclooxygenase II (COX-2), which plays a key role in eicosanoid biosynthesis. Prostaglandin E2 is considered to be the major mediator molecule of COX-2, which triggers cellular proliferation and angiogenesis, inhibits apoptosis, enhances invasive specificity and modulates immunosuppression. COX-2 is considered to be an important therapeutic target for the reason that it is overexpressed at a significant level in various tumors, including colorectal neoplasia (10).

In addition to $\mathrm{COX}-2$, prostaglandin formation is also directly associated with the presence of free arachidonic acid. Arachidonic acid is released with fatty acid hydrolysis by phospholipase $\mathrm{A}_{2}$ enzyme ( $\left.\mathrm{PLA}_{2}\right)$ from the sn2 position of the membrane glycerophospholipids and is subsequently metabolized by COX to form prostaglandins and thromboxanes $(11,12) . \mathrm{PLA}_{2}$ is a key regulatory enzyme for the metabolism of arachidonic acid leading to the synthesis of prostaglandins via COX pathways $(13,14)$. In human cells various types of $\mathrm{PLA}_{2}$ enzymes can be found. Among them, it has been suggested that the $85 \mathrm{kDa}$ cPLA2 is a major intracellular form and plays an essential role with COX-2 in releasing arachidonic acid which is induced by stimulation (15). It is also suggested that CPLA2 participates in the induction of intestinal tumor because of its key role in prostaglandin production. Yoo et al. (16) have investigated the effects of cPLA2, prostaglandin dehydrogenase and COX-2 expression on colorectal cancer tumor formation and found that cPLA2 expression is closely associated with COX-2 expression and may play an important role in tumor progression.

Recent studies have shown that some members of the protein family known as Annexins, have significant anti-inflammatory roles. Annexins are a family of $\mathrm{Ca}^{2+}$ dependent proteins that bind to membrane phospholipids $(17,18)$. Proteins of this multiple gene family, defined by different structural and biochemical criteria, are involved in various biological processes. These processes include regulating the membrane organization, membrane traffic, membrane-cell skeleton connection, and intermembrane ion conduction. It has also been suggested that members of the Annexin family act as anti-inflammatory and anticoagulant components as well as playing regulatory or mediatory roles in certain cell-cell and cellmatrix interactions. The anticoagulant and antiinflammatory effects of the Annexins are probably explained by membrane-substrate consumption; because Annexins compete with $\mathrm{PLA}_{2}$ and blood coagulation factors in order to bind to the cell membrane and thus reduce the availability of the substrate (19). 
AnxAI is the first characterized member of the Annexin family and was identified in the late 1970s. While it was first known as macrocortin (20), renocortin (21) and lipomodulin (22), later it was named as lipocortin I and finally AnxAI. The gene coding AnxAI protein is localized in chromosome 19q24 (23). This $37 \mathrm{kDa}$ protein has $\mathrm{Ca}^{2+}$ and phospholipid binding properties and is found to be involved in the inhibition of glucocorticoid-induced $\mathrm{PLA}_{2}$ and eicosanoid synthesis.

With the present study, it was aimed to measure circulating levels of AnxA1 protein and also its mRNA expression levels in colorectal cancer patients and to investigate the relationship between changes in protein levels and various inflammation markers

\section{MATERIALS and METHODS}

\section{Subjects}

Eighty-two patients who were diagnosed as colorectal cancer were recruited from the patient population attending to Clinical Oncology Department of Ankara University Medical School for this study. Seventy-four of those patients including 30 women and 44 men and with a mean age of $61.52 \pm 11.16$ were included in the analyses. The exclusion criteria of the study were a personel history of vascular, thromboembolic or hemorrhagic disease and inheritance relationship between volunteers. Seventy-nine volunteers without history of any vascular, hemorrhagic and thromboembolic diseases were formed the control group. On the other hand, in order to prevent the wrong positive results of Elisa applications, the volunteers with any known autoimmune diseases were also excluded from the study. All experiments were performed in compliance with the relevant laws and institutional guidelines. Ankara University Medical School Ethics Committee has approved the experiments and informed consents were obtained from each participant before enrollment. After an overnight fast of 812 hours, venous blood samples were collected into EDTA containing tubes for total RNA isolation and for all Elisa measurements. The samples were stored in $-80^{\circ} \mathrm{C}$ until assayed.

\section{Data collection}

The following data were extracted from the Electronic Medical Records (EMR) as available for each subject of patient population: age, gender, CEA, site and histological type of tumor, the presence of bowel perforation and obstruction at diagnosis and the histological type and grade of carcinomas. All subsequent patient measures were extracted from the EMR as in time of sample collection date.

\section{ELISA Measurements}

Serum Annexin I levels were detected by enzyme-linked immunosorbent assay (ELISA) using a commercially available Elisa Kit (Eastbiopharm,\#CK-E91061) according to the manufacturer's instructions. The analytical sensitivity was $0.11 \mathrm{ng} / \mathrm{mL}$. The assay range of kit was $0.3-90 \mathrm{ng} / \mathrm{ml}$. Levels of circulating IL-6 were determined by elisa technique using high-sensitivity commercial kits (eBioscience, \#BMS213/2). The limit of detection of human IL-6 of the kit was $0.92 \mathrm{pg} / \mathrm{ml}$ and the calculated overall intra- and inter-assay coefficient of variation was $3.4 \%$ and $5.2 \%$, respectively. $\mathrm{cPLA}_{2}$ and $\mathrm{SPLA}_{2}$ activities were also detected using commercially available kits (Cayman, \#765021, \#765001, respectively). According to the sensitivity data of cPLA $_{2}$ assay kit, samples containing cPLA ${ }_{2}$ activity between $3.5-42 \mathrm{nmol} / \mathrm{min} / \mathrm{ml}$ could be assayed without further dilutions. The detection range of $\mathrm{SPLA}_{2}$ assay was from 0.02 to $0.2 \mu \mathrm{mol} / \mathrm{min} / \mathrm{ml}$ of sPLA $_{2}$ activity and the intra- and inter-assay coefficient of variation $2.5 \%$ and $4.2 \%$, respectively.

\section{PCR Analyses}

Annexin I and PLA $\mathrm{P}_{2}$ mRNA expression levels were determined by real-time PCR technique. Briefly, total RNA was isolated from whole blood samples using RNA isolation kit (Roche, Germany). cDNA was synthesized with the PCR system using a transcriptor high fidelity cDNA synthesis kit (Roche, Germany). Quantitative real-time PCR was performed using the Qiagen Rotorgene system. The results were normalized by using $\beta$-actin (ACTB) as housekeeping gene. The analyses were performed in duplicates. The forward and reverse primers were loaded to RT-PCR with the identification numbers given below: AnxAl Qiagen single assay identification number 
PPH02882E; $\quad \mathrm{PLA}_{2}$ Qiagen single assay identification number PPH06245E; ACTBQiagen single assay identification number PPH000736.

\section{Statistical Analysis}

The statistical analyses were performed by GraphPad Prism (version 6.0e; GraphPad Software Inc). The data for AnxI protein and PLA2 levels were expressed as mean \pm SD and compared using a Student's $t$ test. Correlation analyses were performed within the Pearson correlation test. Values of $\mathrm{p}<0.05$ were considered as statistically significant.

\section{RESULTS}

Demographic and clinical characteristics of the study groups were given in Table 1 . Mean age of the control group was lower than patients whereas the percent of gender was similar in both groups.
Levels of AnxA1 and inflammatory mediators were given in Table 2. AnxA1 levels in patients with colorectal cancer $(14.54 \pm 9.87$ $\mathrm{ng} / \mathrm{ml}$ ) were significantly lower when compared to control $(29.70 \pm 16.62 \mathrm{ng} / \mathrm{ml}$, $\mathrm{p}<0.0001$ ) (Figure 1). Circulating IL-6 levels of patient group $(5.04 \pm 2.89 \mathrm{pg} / \mathrm{ml})$ was significantly higher than control group $(2.98 \pm 1.26 \mathrm{pg} / \mathrm{ml}, \mathrm{p}<0.0001)$. The measured sPLA $_{2}$ activity of patient group $(0.011 \pm 0.009$ $\mu \mathrm{mol} / \mathrm{min} / \mathrm{ml}$ ) was significantly lower than control $(0.009 \pm 0.003 \mu \mathrm{mol} / \mathrm{min} / \mathrm{ml}, \mathrm{p}=0.0282)$, whereas the $\mathrm{cPLA}_{2}$ activities were similar in both groups $(\mathrm{p}=0.3517)$ (Table 2$)$.

The results of genetic analyses were given in Figure 1 as fold regulation values. According to the real-time PCR data, AnxA1 mRNA expression has been down-regulated in patient group $(\mathrm{p}=0.003)$ and PLA2 mRNA results displayed an up-regulation in patient group with a 1.4432 fold regulation value $(\mathrm{p}<0.001)$.

Table 1: Subject Characteristics

\begin{tabular}{|l|c|c|c|}
\hline Variable & $\begin{array}{c}\text { Control } \\
(\mathrm{n}=79)\end{array}$ & $\begin{array}{c}\text { Patient } \\
(\mathrm{n}=74)\end{array}$ & P value $^{\#}$ \\
\hline Age, mean \pm SD & $35.36 \pm 1.12$ & $61.52 \pm 11.16$ & $<0.001$ \\
\hline Male, \% & 49.15 & 59.45 & NS \\
\hline Site & ND & & \\
\hline Left colon, \% & & 10.81 & \\
\hline Right colon \% & & 28.37 & \\
\hline Sigmoid, \% & & 39.19 & \\
\hline Rectum, \% & ND & - & \\
\hline Bowel perforation at diagnosis, \% & ND & 6.76 & \\
\hline Bowel obstruction at diagnosis, \% & ND & & \\
\hline Histological type & & 79.72 & \\
\hline Adenocarcinoma & & 20.28 & \\
\hline Mucinous adenocarcinoma & ND & & \\
\hline Histological differentiation & & 79.73 & \\
\hline Grade 2 & & $82.29 \pm 228.92$ & \\
\hline Grade 3 & & $(0.15-1011.90)$ & \\
\hline CEA & & Stand & \\
\hline
\end{tabular}

Abbreviations: ND, not determined, NS, not significant \# Statistical comparisons were performed between control and colorectal cancer patient groups. 
Table 2. Results of ELISA measurements

\begin{tabular}{|l|c|c|c|}
\hline & $\begin{array}{c}\text { Control } \\
(\mathrm{n}=79)\end{array}$ & $\begin{array}{c}\text { Patient } \\
(\mathrm{n}=74)\end{array}$ & P value \\
\hline $\begin{array}{l}\text { AnxA1, } \\
\mathrm{ng} / \mathrm{ml}\end{array}$ & $29.70 \pm 16.62$ & $14.54 \pm 9.87$ & $<0.0001$ \\
\hline $\begin{array}{l}\mathrm{IL}-6, \\
\mathrm{pg} / \mathrm{ml}\end{array}$ & $2.98 \pm 1.26$ & $5.04 \pm 2.89$ & $<0.0001$ \\
\hline $\begin{array}{l}\mathrm{cPLA} 2 \\
\text { activity, } \\
\mu \mathrm{mol} / \mathrm{min} / \\
\mathrm{ml}\end{array}$ & $0.011 \pm 0.002$ & $0.012 \pm 0.006$ & 0.3517 \\
\hline $\begin{array}{l}\text { sPLA } 2 \\
\text { activity, } \\
\mu \mathrm{mol} / \mathrm{min} / \\
\mathrm{ml}\end{array}$ & $0.009 \pm 0.003$ & $0.011 \pm 0.009$ & 0.0282 \\
\hline
\end{tabular}

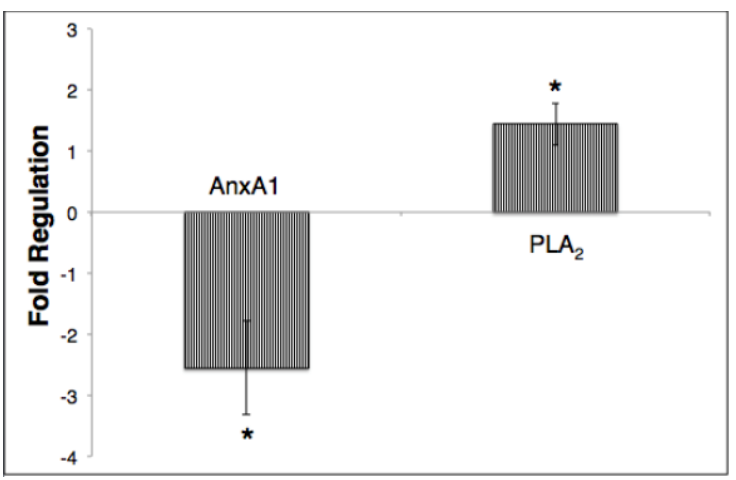

Figure 1. The results of real-time PCR experiments. The up-/down-regulation of AnxA1 and $\mathrm{PLA}_{2}$ genes in colorectal cancer patients were given as fold regulation levels. The data represent a down-regulation of AnxA1 mRNA expression, whereas $\mathrm{PLA}_{2}$ expression is significantly upregulated.

*represents the significance of $\mathrm{p}<0.05$ compared to control.

\section{DISCUSSION}

The relationship between inflammation and cancer, based on epidemiological and experimental data $(24,25)$ has been confirmed by the efficacy of anti-inflammatory therapy in the prevention and treatment of cancer (26).

Functions of Annexins, defined as antiinflammatory (27) and immunosuppressive (28) agents, indicate that these proteins function as normal protective regulators in the extracellular environment.

Since individual annexins have been implicated in tumor development and progression, the studies have focused on investigating their roles on different cancer types. Among annexin proteins, AnxA1 has been reported to Show altered expression in a variety of cancers, including pancreatic cancer (29), hair cell leukemia (30), oesophageal cancer (31) and it's also been reported to be overexpressed in colorectal cancer cells (32).

AnxA1 was detected at concentrations of $50 \mathrm{ng} / \mathrm{ml}$ in a large number of cells and tissues (lung, bone marrow, bowel) and at the highest concentration of $150 \mathrm{ng} / \mathrm{ml}$ in the seminal fluid (33). It forms $2-4 \%$ of total cytosolic protein and is found in gelatinase granules in neutrophils. Although neutrophils released out have low levels of AnxA1, when the gelatinase granules are released, AnxA1 is also released by endothelial vascular adhesion (34). It is thought that when AnxA1 is released, it binds to its receptor and mediates the cellular detachment of neutrophils and blocks the inflammatory response by inhibiting transmigration of leukocytes (35). Decreased AnxA1 levels are thought to disinhibit the action of known inflammatory mediators such as $\mathrm{SPLA}_{2}$ and interleukin-1(27).

The activity of AnxA1, identified as a $\mathrm{PLA}_{2}$ inhibitor, had previously been linked to its antiinflammatory effects (36). However, today it is known that AnxA1 directly inhibits $\mathrm{PLA}_{2}$, not via its mechanism of substrate consumption. Kim et al. (37) showed this direct interaction between AnxA1 and PLA 2 , and this finding was later confirmed by demonstrating that the phosphorylation and activation of $\mathrm{CPLA}_{2}$ is inhibited by AnxA1(38). However, the interaction between AnxA1 and $\mathrm{PLA}_{2}$ is not very clear and has only been observed in a cellular sense. In a subsequent study, the functional relationship between phosphorylated AnxA1 and $\mathrm{CPLA}_{2}$ was demonstrated in the hepatocyte cell line (39). AnxA1 has also been shown as an endogenous determinant mediating the proresolving properties of cyclic AMP elevating agents (40). The importance of AnxA1 in colorectal cancer has been indicated with another finding which remarked higher AnxA1 expression and its association with carcinoembryogenic antigen levels (41). A study by Duncan et. al. (42) has shown that specific annexins, including AnxA1, are present in colorectal cancer and annexin expression profile is associated with survival.

In our study, AnxA1 levels were observed to be decreased significantly in colorectal cancer patients. However, the significant increase in IL-6 and sPLA 2 levels 
indicate the inflammatory state in the patients group. Correlation analysis showed a poor negative correlation between the inflammation markers and AnxA1 in the patients group.

While the two well-defined classes of $\mathrm{PLA}_{2}, 14 \mathrm{kDa} \mathrm{sPLA}_{2}$ and $85 \mathrm{kDa} \mathrm{cPLA}_{2}$, require the presence of a certain amount of $\mathrm{Ca}^{2+}$ in order to function, the presence of $\mathrm{Ca}^{2+}$ is an absolute necessity for interfacial bindings of Annexins. Buckland et al., (43) have shown that AnxV can inhibit cPLA2 activity by its substrate consumption mechanism and that this inhibition is dependent on the concentration of $\mathrm{Ca}^{2+}$ ions in the phospholipids and the environment.

With the growing incidence of colorectal cancer, it has become an increasingly important problem to reduce the development of inflammation in the treatment of the disease as well as the other factors that cause cancer. This is the first study to evaluate Annexin proteins in colorectal cancer. Data obtained showed that AnxA1 protein levels and mRNA expression decreased significantly in colorectal cancer patients and that there's a correlation between this reduction and inflammation development. Further studies are needed to clarify the pathogenetic and clinical effects of the AnxA1 system in colorectal cancer patients.

\section{Acknowledgets}

This study was supported by Ankara University Research Foundation with 13B3336002 project number.

Disclosure summary: The authors declare that they have no conflict of interest concerning this article.

\section{REFERENCES}

1. Boyle $\mathrm{P}$, Leon ME. Epidemiology of colorectal cancer. Br Med Bull. 2002;64:1-25.

2. Yang J, Peng JY, Chen W. Synchronous Colorectal Cancers: A Review of Clinical Features, Diagnosis, Treatment, and Prognosis. Digestive Surgery. 2011;28:379-85.

3. Larsson SC, Orsini N, Wolk A. Diabetes mellitus and risk of colorectal cancer: a metaanalysis. J Natl Cancer Inst. 2005;97:1679-87.

4. Eser S, Yakut C, Ozdemir R, Karakilınc H, et al. Cancer Incidence Rates in Turkey in 2006: A Detailed Registry Based Estimation. Asian Pacific J Cancer Prev. 2010;11:1731-39.
5. Mantovani A, Allavena $P$, Sica $A$, Balkwill $F$. Cancer-related inflammation. Nature. 2008; 454:436-44.

6. Lakatos PL, Lakatos L. Risk for colorectal cancer in ulcerative colitis: changes, causes and management strategies. World J Gastroenterol. 2008;14:3937-47.

7. Hussain SP, Harris CC. Inflammation and cancer: an ancient link with novel potentials. Int J Cancer. 2007;121:2373-80.

8. Williams CS, Mann M, DuBois RN. The role of cyclooxygenases in inflammation, cancer, and development. Oncogene. 1999;18:7908-16.

9. Lagorce-Pages C, Paraf F, Wendum D, et al. Expression of inflammatory secretory phospholipase A2 and cytosolic phospholipase A2 in premalignant and malignant Barrett's oesophagus. Virchows Arch. 2004;444:426-35.

10. Arber N. Cyclooxygenase- 2 inhibitors in colorectal cancer prevention: point. Cancer Epidemiol Biomarkers Prev. 2008;17:1852-57.

11. Balsinde J, Balboa MA, Insel PA, Dennis EA. Regulation and inhibition of phospholipase A2. Annu Rev Pharmacol Toxicol. 1999;39:175-89.

12. Chang J, Musser JH, McGregor $\mathrm{H}$. Phospholipase A2: function and pharmacological regulation. Biochem Pharmacol. 1987;36:2429-36.

13. Yoo YS, Lim SC, Kim KY. Prognostic significance of cytosolic phospholipase A2 expression in patients with colorectal cancer. J Korean Surg Soc. 2011;80:397-403.

14. Laye JP, Gill JH. Phospholipase A2 expression in tumors: a target for therapeutic intervention. Drug Discov Today. 2003;8:710-16

15. Panel V, Boëlle PY, Ayala-Sanmartin J, et al. Cytoplasmic phospholipase A2 expression in human colon adenocarcinoma is correlated with cyclooxygenase- 2 expression and contributes to prostaglandin E2 production. Cancer Lett. 2006;243:255-63.

16. Lim SC, Cho H, Lee TB, et al. Impacts of cytosolic phospholipase A2, 15-prostaglandin dehydrogenase, and cyclooxygenase-2 expressions on tumor progression in colorectal cancer. Yonsei Med J. 2010;51:692-99.

17. Raynal P, Pollard HB. Annexins: The problem of assessing the biological role for a gene family of multifunctional calcium- and phospholipidbinding proteins. Biochim Biophys Acta. 1994;1197:63-93.

18. Swairjo MA, Seaton BA. Annexin structure and membrane interaction: A molecular perspective. Annu Rev Biophys Biomol Struc. 1994;23:193213.

19. Davidson FF, Lister MD, Dennis EA. Binding and inhibition studies on lipocortins using phosphatidylcholine vesicles and phospholipase A2 from snake venom, pancreas and a macrophage-like cell line. J Biol Chem. 1990;265:5602-09.

20. Blackwell GJ, Carnuccio R, Di Rosa M, Flower RJ, Parente L, and Persico P. Macrocortin: a polypeptide causing the anti-phospholipase effect of glucocorticoids. Nature. 1980;287:14749. 
21. Rothhut B, Russo-Marie F, Wood J, DiRosa M., Flower RJ. Further characterization of the glucocorticoidinduced antiphospholipase protein "renocortin". Biochem Biophys Res Commun. 1983;117:878-84.

22. Hirata F, del Carmine R, Nelson CA, et al. Presence of autoantibody for phospholipase inhibitory protein, lipomodulin, in patients with rheumatic diseases. Proc Natl Acad Sci USA. 1981;78:3190-94.

23. Lim LHK, Pervaiz S. Annexin I: the new face of an old molecule. The FASEB Journal. 2007;21:968-75.

24. Grivennikov SI, Greten FR, Karin M. Immunity, inflammation, and cancer. Cell. 2010;140:883-99.

25. Grivennikov SI, Karin M. Inflammation and oncogenesis: a vicious connection. Curr Opin Genet Dev. 2010;20:65-71.

26. Gonda TA, Tu S, Wang TC. Chronic inflammation, the tumor microenvironment and carcinogenesis. Cell Cycle. 2009;8:2005-13.

27. Flower RJ, Rothwell NJ. Lipocortin-l--cellular mechanisms and clinical relevance. Trends Pharmacol Sci. 1994;15:71-6.

28. Sakata T, Iwagami S, Tsuruta Y, Suzuki S, Suzuki R. Study of natural lipocortin I-a potent mediator for macrophage-mediated immunosuppression in tumorbearing mice. Immunol. 1993;151:4964-72.

29. Bai XF, Ni XG, Zhao P, Liu SM, Wang HX, Guo B, Zhou LP, Liu F, Zhang JS, Wang K, Xie YQ, Shao YF, Zhao XH. Overexpression of annexin 1 in pancreatic cancer and its clinical significance. World Gastroenterol. 2004;10:1466-1470.

30. Falini B, Tiacci E, Liso A, et.al. Simple diagnostic assay for hairy cell leukaemia by immunocytochemical detection of annexin A1 (ANXA1) Lancet. 2004;363:1869-70.

31. Wang KL, Wu TT, Resetkova E, et.al. Expression of annexin A1 in esophageal and esophagogastric junction adenocarcinomas: association with poor outcome. Clin Cancer Res. 2006;12: 4598-604.

32. Guzman-Aranguez A, Olmo N, Turnay J, et.al. Differentiation of human colon adenocarcinoma cells alters the expression and intracellular localization of annexins A1, A2, and A5. J Cell Biochem. 2005; 94:178-93.

33. Christmas P, Callaway J, Fallon J, Jones J, Haigler HT. Selective secretion of annexin 1, a protein without a signal sequence, by the human prostate gland. J Biol Chem. 1991;266: 249907.

34. Perretti M, Flower RJ. Measurement of lipocortin 1 levels in murine peripheral blood leukocytes by flow cytometry: modulation by glucocorticoids and inflammation. $\mathrm{Br} \quad \mathrm{J}$ Pharmacol. 1996;118:605-10.

35. Lim LH, Solito E, Russo-Marie F, Flower RJ, Perretti M. Promoting detachment of neutrophils adherent to murine postcapillary venules to control inflammation: effect of lipocortin 1. Proc Natl Acad Sci USA. 1998;95:14535-39.

36. Errasfa M, Russo-Marie F. A purified lipocortin shares the anti-inflammatory effect of glucocorticosteroids in vivo in mice. $\mathrm{Br} \mathrm{J}$ Pharmacol. 1989;97:1051-58.

37. Kim KM, Kim DK, Park YM, Kim CK, Na DS. Annexin-I inhibits phospholipase A2 by specific interaction, not by substrate depletion. FEBS Lett. 1994;343:251-55.

38. Croxtall JD, Choudhury Q, Tokumoto H, Flower RJ. Lipocortin-1 and the control of arachidonic acid release in cell signalling. Glucocorticoids (changed from glucorticoids) inhibit $G$ protein-dependent activation of cPLA2 activity. Biochem Pharmacol. 1995;50: 465-74.

39. De Coupade C, Gillet R, Bennoun M, Briand P, Russo-Marie F, Solito E. Annexin 1 expression and phosphorylation are upregulated during liver regeneration and transformation in antithrombin III SV40 T large antigen transgenic mice. Hepatology. 2000;31:371-80.

40. Lima KM, Vago JP, Caux TR, et.al. The resolution of acute inflammation induced by cyclic AMP is dependent on annexin A1. J Biol Chem. 2017; 292(33): 13758-773.

41. Ydy LR, do Espírito Santo GF, de Menezes I, et. al. Study of the Annexin A1 and Its Associations with Carcinoembryonic Antigen and Mismatch Repair Proteins in Colorectal Cancer. J Gastrointest Cancer. 2016; 47(1): 618 .

42. Duncan R, Carpenter B, Main LC, et.al. Characterisation and protein expression profiling of annexins in colorectal cancer. $\mathrm{Br} \mathbf{J}$ Cancer. 2008; 98(2): 426-33.

43. Buckland AG, Wilton DC. Inhibition of human cytosolic phospholipase A2 by human annexin V. Biochem J. 1998; 329: 369-72. 